\title{
Tracking possibilities in the poultry sector - a review
}

\author{
ÁGNES TÓTH ${ }^{1}$, KATALIN KOVÁCSNÉ GAÁL'1, ZSOLT TURCSÁN², NOÉMI ÁSVÁNYI- \\ MOLNÁR ${ }^{1}$, BALÁZS ÁSVÁNYI', JENŐ SZIGETI' ${ }^{1}$ and HEDVIG FÉBEL ${ }^{3}$ \\ 'University of West-Hungary, Faculty of Agriculture and Food Sciences Institute of Food Science, Mosonmagyaróvár, \\ Hungary, ${ }^{2}$ P.S.S. Plus Innovation Ltd., Mezőkovácsháza, Hungary, ${ }^{3}$ The Research Institute for Animal Breeding and \\ Nutrition, Herceghalom, Hungary
}

\section{Abstract}

In accordance with the regulations, the Cross Compliance law in Hungary is estimated to be put into practice from 2009, with which the tracking, registration and marking of animals, furthermore the food safety will receive a more elaborated role. That is why we provide a full-scale review of traceability opportunities of the poultry sector.

The Poultry Information System (PIS) could create a more perspicuous poultry sector, however, its extremely high need of administration is an obligation hard to put up with for the breeders. The means of bird marking, such as the use of leg bands, wing tags, nasal markers, and the individual marking with transponders, based on radio-frequency identification were developed in order to overcome the growing need of complying the rules of food safety.

The most up to date mean of marking in the poultry sector is the RFID (radiofrequency identification) technology.

Keywords: traceability, means of bird marking, RFID, radio-frequency identification

\section{Zusammenfassung}

\section{Möglichkeiten des Herkunftsnachweises bei Geflügel}

In Übereinstimmung mit den bestehenden Rechtvorschriften wurde in Ungarn ab 2009 schrittweise ein Herkunftsnachweis tierischer Produkte bis zur Vermarktung und damit eine erhöhte Sicherheit für Nahrungsmittel eingeführt. Diese Studie beschreibt die Möglichkeiten des Herkunftsnachweises bei Geflügel. Das bestehende Geflügelinformationssystem liefert zwar eine gute Übersicht auf dem Gebiet der Geflügelerzeugung ist jedoch mit hohen Kosten für den Geflügelhalter verbunden. Die Nutzung von Fußringen, Flügelnummerierungen, Schnabelmarkierungen vor allem aber die Transpondernutzung, welche auf der Basis von Radiofrequenzen arbeitet, werden beschrieben. Sie sollen dazu beitragen, den ständig wachsenden Anforderungen der Lebensmittelsicherheit besser zu entsprechen. Ausführlich beschrieben wird die modernste Form der Geflügelidentifizierung - das Radio-Frequency-Identification-System RFID).

Schlüsselwörter: Herkunftsnachweis, Geflügelkennzeichnung, RFID, Radio-Frequency Identification 


\section{Introduction}

The need for trustworthy traceability is growing day by day. The recent irregularities of food industry which result mad cow disease, swine fever, Bird Flu, or the occurrence of dioxin-tainted food in commercial trade ruined the trust of customers in the quality of origin of food. That is why traceability became basic requirement, and the regulations of food safety got stricter (KECSKÉS 2004). According to MCKEAN (2001) to diverge of food production and trade from the direct sell was the main trigger of the upcoming need of tracking, mentioned above.

In accordance with the regulations, the requirement system of the Cross Compliance Law (being put into practice in Hungary from 2009) provides a more elaborated rule to food safety, the animal marking and administrating. Owing to the fact that a full-scale review is needed, we deliver a broad survey of the topic.

\section{Tracking}

Tracking is defined by the ISO 8402:1992 standard as: stracking ability of the walk of life of a certain product, the processes which it undergoes, and its spatial position, on the basis of fixed informations.

The purpose of traceability is to run an information system which literally tracks the physical movement of the product (SIMCHI-LEVI et al. 2003). With the use of the information system the source of an occurring pollution could be indicated, defined and separated. As a result, the withdrawal of a certain product, or its extraction from commercial trade simplifies. In order to secure the perfect run of the system, each participants of the food producing chain have to record any movements between the units, as well as the processes of food production (FÜZESI 2005). Two means of tracking could be distinguished. We can either follow the way of a product backward on the food chain, or we can track all the various products, which were made of the same raw-material. The latter method is essential if the withdrawal of a certain product is to be initiated (BENCSIK and FÜZESI 2007a). Tracking a product naturally needs a supervising chain, which is able to keep up credibility and to complete information transferring functions. Moreover, an identification system is needed, and a credible and verifiable mechanism for identity preservation (MCKEAN 2001). Tracking and product withdrawing systems support the gathering of valuable data, not to mention that they help preventing human diseases. Furthermore they could be useful for governments recognizing the potential dangers connected to food (NATIONAL RESEARCH COUNCIL 1985). Tracing systems can be subdivided into the following four categories, according to what is prior for us to know: country of origin; retail; processor; and farm-to-retail identity (MCKEAN 2001).

\section{Legal background of tracking}

The first law, mentioning tracking systems is the 2003/LXXXII Food Law. The Regulation EC 178/2002 refers to the compulsory use of a tracking system in the food industry, which is based on authoritative data. According to the Regulation (EC) No 852/2004 On the hygiene of foodstuffs the cornerstone of food safety assurance is the food and food ingredients traceability in the food industry. The 119/2007.(X.18.) Ministry of Agriculture and Rural Development (MARD) regulation orders the operation of the Raising 
Information System (RIS) which registers all the data in connection with raising plants, raising methods, etc. The purpose of the system is to register all the plants, producing for commercial trade (MARLOK 2008).

The spreading of bird epidemics, primarily the bird flu, forced the EU to register all the plants where the threat of diseases is very likely because of the large amount of poultry raised. The rule also orders the tracking of stock movement (ANTAL 2007).

In order to track the poultry movement, the Poultry Information System (PIS) was developed, ordered by the law 120/2007.(X.18.) MARD. The law assesses the use of bill of delivery which contains all the needed data, and which could be processed by computers. The above mentioned bill of delivery is identical for every poultry raisers, who are compulsorily registered in the RIS. The birds which are obligatory to be registered: chicken, turkey, duck, goose, guinea-fowl, pigeon, pheasant, grey partridge, quail, ostrich, emu.

\section{The PIS (Poultry Information System)}

Nowadays the poultry sector is the most scomplicated sector in the respect of administration. In the commercial trade the individual identification of the poultry is neither general, nor widespread, only the sires undergo it (FALLON 2001).

Owing to the orders of the MARD regulation, introduced in the poultry sector of Hungary in 2007-2008, an administration system is being developed, in order to continue a tendency, since the beef, pork, sheep, and goat industries have already had a system, being similar to the ENAR (identification and registration system for animal in Hungary), which operates in the livestock-industry. The above mentioned administration system makes the Cross Compliance possible, which is needed for the applications for various benefits, provided by the general farm-sponsorship system, starting this year. At the other hand, it restricts the circulation of illegal animal stock, making the run of food industry more controllable (MARLOK 2008).

The system is designed for tracking the geographical movements of animal stocks, consequently, the bills of delivery are compulsory to use when any movement happens between breeding or hatchering eggs, or between living, registered breeds. Five issues of bills are to fill, indicating the RIS registration number of both the sending and receiving breeder. Deliveries are recorded by the National Database that is why the sending breeder is in charge with sending the first issue of the bill to the ENAR center in seven days. The second and third issues are attached to the moving stock. The receiving breeder, after indicating the data of receiving on the second bill, is to send it to the ENAR center in seven days. The fourth issue is the property of the veterinarian, the fifth one remains at the sender. The basic idea of the system is that only legal stocks with wellknown origin should take part in commercial trade, or transferred to the slaughterhouses. That is why the new-coming stocks are treated with particular rigor (MARLOK 2008). The identification and documentation supports the trust in the safety of the product, checks the health risk of the use of the products, furthermore it simplifies the withdrawal of the products (CAPORALE et al. 2001).

According to MARLOK (2008) with the run of PIS, the obligation of administration of stock, and the means of breeding data service is altered. Confirming the origin of poultry 
stock is still the right and obligation of the breeder. Confirming documents are to fill as soon as the new-born stock arrives. However, the stock identification number, generated by the breeding authority, only given after the data of the documents of origin is authentically confirmed. The process of confirmation means that the data on the documents of origin is contrasted with the data, stored by the PIS databases.

The proper use of the system could make the poultry sector more controllable. Moreover, it could prevent the circulation of illegal stock, and the dishonest manipulations. As a drawback, it has an extremely high need of administration, more working hours and manpower.

\section{Review of the means of poultry marking}

Animal marking systems are widely used by experts. The basic principles are the opportunities of observability and storage of the needed information, not to mention the option that researchers - if needed - can tell the different individuals from each other during the experiments. The results of researches are highly influenced by these systems. It is important that the used marking methods must not spoil the outcomes during the processes (DENNIS et al. 2008).

Traceability of animals is only materialized if the individuals are marked. Identification of animals ensures that we can investigate the walk of life of the animal backwards, ,from the table to the farm . It provides the option of determining who is in charge with the financial consequences of food-based diseases, and who has to deal with the prevention connected to the food industry (VITIELLO and THALER 2001). During the following sections, all the poultry marking methods are enlisted.

For marking birds, leg bands, wing tags, nasal markers are used. The serial numbered leg bands and wing tags are the basic methods, despite of the fact that if young individuals outgrow them, tissue deformation is likely to occur, furthermore it can endorse pecking (HANNON et al. 1990, JACKSON and BÜNGER 1993). For marking waterfowls, marking the leg by slitting the web could be used, but only if the process happens when the individual is only few days old, as ordered by the 6th appendix of the 32/1999 (III. 31.) MARD regulation. Birds could be also marked with paint in different body parts (WADKINS 1948) with leg flags, or neck collars (BARTELT and RUSCH 1980, SAMUEL et al. 1990). These methods simply cannot provide more than the opportunity of identification. They are unable to bear any other information.

Various studies use marking, such as ethological studies (ESTEVEZ et al. 2003, DENNIS 2004) wildlife researches (MELLOR et al. 2004) and studies on reproduction (BRODERICK and GODLEY 1999). According to DENNIS (2004) marking the head or neck of the poultry generates increase in aggression against each other. Based on the results of the study, DENNIS et al. (2008) made further researches in order to investigate the effects of different marking technologies on chickens. During the experiment, the animals were kept in cages, individuals were divided into four groups. The individuals of the first group were marked with leg bands, the animals of the second group were wing tagged, members of the third group got neck collars, feathers on the back of the chickens of the third group were painted. A control group was chosen in order to contrast with the four marked groups. It was proved that when couples are kept in a cage, wing tags and leg bands generates 
pecking, which means increased stress level. Previous experiments (GUHL 1953, GUHL and ORTMAN 1953) proved that any alternation in the appearance of poultry (such as marking feather and crest) has an effect on how they behave (DENNIS et al. 2008).

\section{Wing marking (wing tags, patagial tags)}

The tag itself is made of plastic or metal, attached to the patagium. It indicates which tribe the bird belongs to. Moreover the migration of the bird could be also tracked (WEAVER 1981). Patagial tags are frequently used when studies on waterfowls are conducted (BRUA 1998). ANDERSON (1963) was the first to report the use of wing tags. For marking waterfowls, studying their behavior, tracking their migration wing tags are being used since then. Their advantage is their long range visibility and durability (BUSTNES and ERIKSTAD 1990). However, BRUA (1998) found out that according to the results of his studies, these marking methods cannot be used for marking ruddy duck (Oxyura jamaicensis), since marked individuals are tend to sleep and preen more, their courtship behavior was less active, in contrast with the leg banded individuals.

\section{Leg bands}

The most widely used method among breeders. KOSSACK (1950) initiated the use of colored leg bands as a mean of marking. Generally, for marking poultry, the colored plastic leg bands are used. It was proved that different colors transmit different information to the fellow poultry members, which may have an effect on the reproductive properties (BURLEY 1981, 1988).

\section{Nasal markers}

LOKEMOEN and SHARP (1985) conducted a 6 year long ethological study, during which they were examining the mallard (Anas platyrhynchos), gadwall (Anas strepera) and bluewinged teal (Anas discors) reproduction in central North Dakota. During the experiment a seafowl marking method was essential, which is easy to identify from 4-500 meters distance, for 6 years at least. The purpose was to develop a system which makes possible the marking of 500 individuals. That is why the experts decided to use nasal markers as the most suitable solution. The first who reported its use for marking ducks was EVRARD (1996). PELAYO and CLARK (2000) developed a modified nasal marker with which teals and other members of the Oxyurinae family could be also examined. This was not an option before, because of the special shape of the beak these birds.

In order to eliminate the harmful effects of the above mentioned marking methods, and for decreasing the administration need, the radio-frequency based identification technology (RFID) is being universalized.

\section{RFID technology as a possible mean of marking poultry}

According to SAHIN et al. (2002), RFID (radio-frequency identification) as a new marking method ensures the full-scale tracking of livestock and poultry as well.

The RFID is an identification system which transmits the custom identifiers of an object (a bird, in our case) with radio frequency. Three basic elements are needed for its run: an RFID tag, a reading unit and a background database. The RFID tag (stransponders 
or stags in the following) is a chip, containing the data of the object. The data, stored on the chip could be digitalized with the help of a reading unit (KÓSA 2007). Consequently, the identification of the animal could be also done easily with the method. The microchip could be extracted from the animal during the slaughter, so besides the one-off cost the expense of the run of the system is much lower (SOLYMOSI and BIACS 2007). In vast majority the RFID applications are passive, because they extract the energy from the radio frequency field of the reader (SZABO 2007). The chip is able to store important information such as the race of the animal, its origin, owner, location, previous medical treatment, vaccines, feeding background, and most importantly the individual identifying code of the animal (BENCSIK and FÜZESI 2007b). Certain implanted microchips could be used for the continuous monitoring of body temperature (KORT et al. 1997). The poultry marking applications, based on RFID are called PIT (Passive Integrated Transponder) tags. It is built up by a coiled electromagnet, a capacitor, a hermetically sealed microchip, which is placed in a bio-compatible glass capsule. (Polypropylene, movement preventing capsules are also used) When the low radiofrequency radiated by the reading unit activates the PIT tag, it radiates an individual code back to the reading unit (JAMISON et al. 2000) with which the individual can be identified. The PIT tags are highly useful for marking animals. They are passive tags hence there is no energy source in them, as a result their size is small enough to be implantable.

\section{Physiological effects of RFID technology}

PIT tags were originally developed for marking fish, however they are widely used nowadays even wild animals are tagged with it, as well as reptiles, amphibians, mammals and birds (ELBIN and BURGER 1994). BECKER and WENDELN (1997) used subcutaneously injected transponders in order to mark common tern (Sterna hirundo). CARVER et al. (1999) contrasted the advantages and drawbacks of the above mentioned new marking technology with the wing tags when conducting a study on virginia quail (Colinus virginianus). During the 84 day long experiment they monitored caducity, weekly bodyweight gain, the durability of transponders and their breakability. There were no significant differences between the effects of transponders on growth $(P=0.558)$ survival $(P>0.050)$. No significant difference was in the breakability in transponders either. $5 \%$ of the group lost their tags. Subcutaneous PIT injection was also used for marking young and grown up individuals of Kakapo (Strigops habroptilus). It was declared that the implanted tags were operating with satisfactory efficiency, and remained in the place of implantation. When using the marking units, no complication appeared, no harmful effect was found on the health and growth of the animal (LOW 2003). APPLEGATE and his colleagues (2000) were examining the effects of the markers on bodyweight gain, survival, transponder keeping of pheasant poultry. Two experiment groups and a control group were formed. The first experiment group was marked with PIT tag when the pheasants were 7 days old. Members of the second group were marked in the 8th day. Naturally, no implantation was made in the control group. It was stated that no difference occurred in measure growth between the PIT tagged and the control group during the 40 days of the experiment. In the first group no individual caducity occurred, however, 8 died from the second and 6 from the control group. Two cases were reported when PIT 
tagged animals were victims of bird cannibalism. When examining the loss of tags, it was diagnosed that one transponder was lost in each groups.

JAMISON and his colleagues (2000) used the same marking method to mark Leghorn chickens, when initiating their experiment. The purpose was to clarify whether the PIT tag causes weight loss or heighten the tendency of pecking. During the experiment, carried out by them, the transponder was implanted under the skin of the nape of the animals. The examined individuals were divided into three groups. In the first and second group, chicks were injected when they were three and seven days old, respectively. Of course, the third group became the control group in which the members have not gotten PIT tags. No significant difference in daily bodyweight gain between the individuals of the first and second group $(P=0.69)$ between the first and the control group $(P=0.59)$ or between the second and the control group $(P=0.85)$ was noted. No difference in weekly bodyweight gain, survival rate, tag keeping between the control and the experimental groups was proved. Consequently their outcomes are matching with the published results of CARVER (1999) and his colleagues. The pecking tendency during the day after injecting the chip, was equal to the results of JACKSON and BÜNGER (1993), who were investigating the effects of microchips on turkey. It was established that no difference occurred in pecking tendency and bodyweight between the control and tagged individuals. JAMISON and his colleagues (2000) reported that tag loss was about $5 \%$, the same result as HANNON and his colleagues (1990) and CARVER and colleagues' (1999). Several causes can generate loss of tags. The transponder could get too close to the implantation site, penetrating into the implantation wound, pierced by the injection. This happens because the birds are small, and the workforce which is in charge with implantation still lacks experience (JAMISON et al. 2000). If medical glue is used for sealing the implantation site, transponder loss rate is significantly reduced (BECKER and WENDELN 1997, CARVER et al. 1999). Jamison and his colleagues (2000) stated that PIT tagged individuals are not showing increased pecking tendency, in contrast with the individuals of the control group.

It could be concluded that development of a new tracking and administrating system in poultry sector would be welcomed, with which the individual poultry could be genuinely identified, tracked during the whole production chain without any doubt. The widespread use of wing tags, leg bands, nasal markers is able to support the above mentioned system. However, the increased need of administration of the mentioned marking methods is a great drawback, a phenomenon, which is excluded by the marking by transponders, since transmitting data could be initiated during the reading of the tag. The only drawback is the risk of loosing the tag, and the need of outstanding attention during its use. Although it needs further costs, if the radio frequency based identification of the poultry was put in practice, suitability to the Rule Governed Economical Laws (RGEL) - which is the part of Cross Compliance rule - would be possible.

\section{Acknowledgements}

This work was funded by a grant (TECH_08-A3/2-2008-0410) from the National Office for Research and Technology, Hungary. 


\section{References}

Anderson A (1963) Patagial tags for waterfowl. J Wildl Manag 27, 284-8

Antal Á (2007) Identification and registration systems. http://odin.agr.unideb.hu/su2007/presentations/S5/ S51_Antal.pdf [in Hungarian] [last accessed 14.06.2010]

Applegate RD, Jamison BE, Robel RJ, Kemp KE (2000) Effects of passive integrated transponders on ringnecked pheasant chicks. T Kansas Acad Sci 103, 150-6

Bartelt G, Rusch DH (1980) Comparisons of neck bands and patagial tags for marking American coots. J Wildl Manag 44, 236-41

Becker PH, Wendeln H (1997) A new application for transponders in population ecology of the common tern. Condor 99, 534-8

Bencsik A, Füzesi I (2007a) The opportunities of RFID usage in case of agricultural companies dealing with chicken husbandry. http://www.avacongress.net/ava2007/presentations/ais/4.pdf [in Hungarian] [last accessed 16.02.2009]

Bencsik A, Füzesi I (2007b) The use of RFID technology in product tracking. Thesis. Universitas Debreceniensis, Center of Agricultural Sciences and Engineering, Faculty of Agriculture, 56 [in Hungarian]

Broderick AC, Godley BJ (1999) Effect of tagging marine turtles on nesting behaviour and reproductive success. Anim Behav 58, 587-91

Brua RB (1998) Negative effects of patagial tags on ruddy ducks. J Field Ornithol 69, 530-5

Burley N (1981) Sex ration manipulation and selection for attractiveness. Science 211, 721-2

Burley N (1988) Wild zebra finches have band-color preferences. Anim Behav 36, 1235-7

Bustnes JO, Erikstad KE (1990) Effects of patagial tags on laying date and egg size in common eiders. J Wildl Manag 54, 216-8

Caporale V, Giovannini A, Francesco C di, Calistri P (2001) Importance of the traceability of animals and animal products in epidemiology. Rev Sci Tech Oie 20, 372-8

Carver AV, Burger LW, Brennan LA (1999) Passive integrated transponders and patagial tag markers for northern bobwhite chicks. J Wildl Manag 63, 162-6

Dennis RL (2004) Effects of marks on aggression and stress in the domestic fowl (Gallus domesticus). MS Thesis. University of Maryland, College Park, USA

Dennis RL, Fahey AG, Cheng HW (2008) Different effects of individual indentification systems on chicken well-being. Poultry Sci 87, 1052-7

Elbin SB, Burger J (1994) Implantable microchips for individual identification in wild and captive populations. Wildl Soc B 22, 677-83

Estevez I, Keeling LJ, Newberry RC (2003) Decreasing aggression with increasing group size in young domestic fowl. Appl Anim Behav Sci 84, 213-8

Evrard JO (1996) Effects of nasal saddles on mallards and blue-winged teal. Wildl Soc B 24(4), 717-21

Fallon M (2001) Traceability of poultry and poultry products. Rev Sci Tech Oie 20, 538-46

Füzesi I (2005) The food safety and product identification nowadays. Acta Agraria Debreceniensis 16, 341 [in Hungarian]

Guhl AM (1953) Social behavior of the domestic fowl. Tech B 73, 1-43

Guhl AM, Ortman LL (1953) Visual patterns in the recognition of individuals among chickens. Condor 55, 287-98

Hannon SJ, Jönsson I, Martin K (1990) Patagial tagging of juvenile willow ptarmigan. Wildl Soc B 18, 116-9

Jackson DH, Bünger WH (1993) Evaluation of passive integrated transponders as a marking technique for turkey poults. J lowa Acad Sci 100, 60-1

Jamison BE, Beyer RS, Robel RJ, Pontius JS (2000) Passive integrated transponder tags as markers for chicks. Poultry Sci 79, 946-8

Kecskés K (2004) Food trackability. The facilities of EAN-UCC-system. The Meat 4, 243-4 [in Hungarian]

Kort WJ, Hekking-Weijma JM, TenKate MT, Sorm V, VanStrik R (1997) A microchip implant system as a method to determine body temperature of terminally ill rats and mice. Lab Anim 32, 260-9

Kósa Zs (2007) Radio Frequency Identification (RFID). Technological Opportunities of the Information Based Society. A study, 3rd volume, 1.2 Edition, 65-80 http://www.nhit.hu/data/101659/Harmadikuj.pdf [in Hungarian] [last accessed 19.02.2009]

Kossack CW (1950) Breeding habits of Canada geese under refuge conditions. Am Midl Nat 43(3), 627-49

Lokemoen JT, Sharp DE (1985) Assessment of nasal marker materials and designs used on dabbling ducks. Wild Soc B 13, 53-6 
Low M, Eason D, Mclnnes K (2003) Evaluation of passive integrated transponders for identification of kakapo, Strigops habroptilus. Emu 105, 33-8

Marlok P (2008) Central registration and traceability system in poultry sector. The Poultry 9, 4-7 [in Hungarian]

McKean JD (2001) The importance of traceability for public health and consumer protection. Rev Sci Tech Oie 20, 363-71

Mellor DJ, Beausoleil NJ, Stafford KJ (2004) Marking amphibians, reptiles and marine mammals: Animal welfare, practicalities and public perceptions in New Zealand. Department of Conservation, Wellington, New Zealand, 1-55

National Research Council (1985) Meat and poultry inspection. The scientific basis of the nation's program. National Academy Press. Washington DC, USA, 209

Pelayo JT, Clark RG (2000) Effects of a nasal marker on behavior of breeding female ruddy ducks. J Field Ornithol 71, 484-92

Sahin E, Dallery Y, Gershwin S (2002) Performance evaluation of a traceability system. An application to the radio frequency identification technology. In: Proceedings of the 2002 IEEE International Conference on Systems, Man and Cybernetics, vol. 3, 210-8

Samuel MD, Rusch DH, Craven S (1990) Influence of neck bands on recovery and survial rates of Canada geese. J Wildl Manage 54, 45-54

Simchi-Levi D, Kaminsky P, Simchi-Levi E (2003) Designing and managing the supply chain: concepts, strategies, and case studies. 2nd Education. McGraw-Hill Irwin, Boston, USA, 354

Solymosi VK, Biacs PÁ (2007) Traceability in feed production and in animal breeding. Hung J Anim Prod $56,171-82$ [in Hungarian]

Szabó Sz (2007) Things that a label-designer should know by heart. Hung Graphics 2, 22-8 [in Hungarian]

Vitiello DJ, Thaler AM (2001) Animal indentification: links to food safety. Rev Sci Tech Oie 20, 598-604

Wadkins LA (1948) Dyeing birds for identification. J Wildl Manag 12, 388-91

Weaver P (1981) The Birdwatcher's Dictionary. A \& TD Poyser Ltd. London, UK, 156

Received 22 April 2009, accepted 19 January 2010.

Corresponding author:

ÁGNES TÓTH

email: totha@mtk.nyme.hu

Institute of Food Science, Faculty of Agriculture and Food Sciences, University of West-Hungary, H-9200

Mosonmagyaróvár, Hungary 